\title{
Status of eel fisheries, stocks and their management in England and Wales
}

\author{
M. Aprahamian ${ }^{(1)}$, A. Walker ${ }^{(2)}$ \\ Received July 28, 2008 / Reçu le 28 juillet 2008 \\ Revised March 22, 2009 / Révisé le 22 mars 2009 \\ Accepted March 24, 2009 / Accepté le 24 mars 2009
}

Key-words: eel, fisheries, management

\section{Abstract}

All continental life stages of eel are exploited in England and Wales. The main fisheries for glass eel are by estuarine dip-nets in the southwest. The main fisheries for yellow and silver eel occur in southern and eastern England, with fyke nets being the preferred instrument. Fishing effort is not directly recorded but is inferred from licence sales. Around 1100 glass eel licenses were sold annually from 1980 to 1994 , increasing to around 2500 in 1998, but declined to about 800 per annum since 2001. Declared catches of glass eel have been below 1-2 $t$ since 2001, compared to 10-70 $t$ in the 1970s and 1980s. Licence sales for yellow and silver eel fisheries (combined) varied from around 1100 to 2900 over the period 1983-2007, peaking in the mid-1980s, mid-1990s and again in 2005-2007. Declared catches peaked in the late 1980s and mid-1990s (peak $280 \mathrm{t}$ ), but have been low since 2001 (mean 29 t). Nett export data suggests catches may be 4 times higher. Eel landings are reported as bycatch from various marine fisheries around the UK coasts, with landings from 2001 to 2007 ranging from 0.2 to $13.7 \mathrm{t}$ per annum. Assessment of stock status is based mainly on catch and catch per unit effort data as there has been little fishery independent survey of eels. There has been a general decreasing trend in both glass eel catches reported to the Agency and in nett export data. Comparing maximum catch levels in the late 1970s-early 1980s with minimum levels in the 2000s suggests that the catch has declined by around 75-95\%. Trends in CPUE are similar, at least until 1998. It is concluded that current glass eel recruitment to the western coast of the UK is approximately $30 \%$ of the pre- 1980 level of recruitment. Yellow and silver eel indices derived from HMRC nett exports or reported catches per licence sold, both suggest that the current estimate of stocks derived from these data are $20 \%$ those of the late 1980 s and mid 1990s. The Reference Condition Model has been used to assess compliance with the EC target (EU regulation 1100/2007). Assessment is at the River Basin District (RBD) level and in most cases a single river has been used to represent the whole RBD. The assessment therefore has a low level of confidence attached to it, and work to improve this is outlined in the paper. A number of options to increase silver eel escapement are presented, specifically reducing fishing pressure, improving access and habitat quality, reducing the impacts of entrainment, controlling predators and stocking, with the interplay of options varying between rivers and basins depending on local priorities. 


\section{RÉSUMÉ}

État des pêcheries d'anguilles, les stocks et leur gestion en Angleterre et au Pays de Galles

Mots-clés : anguille, pêcherie, gestion
Tous les stades continentaux sont exploités en Angleterre et au Pays de Galles. Les principales pêcheries de civelles sont faites en estuaire par tamis dans le sud-ouest. Celles pour l'anguille jaune et l'anguille argentée sont situées dans le sud et l'est de l'Angleterre avec préférentiellement des verveux. L'effort de pêche n'est pas directement enregistré mais déduit de la vente des licences. Environ 1100 licences pour la civelle ont été vendues entre 1980 et 1994, ce nombre augmentant à 2500 en 1998 , mais diminuant à 800 par an depuis 2001. Les captures déclarées de civelles sont en dessous de 1-2 t depuis 2001, alors qu'elles étaient de 10-70 t dans les années 70 et 80 . Les ventes de licences pour la pêche de l'anguille jaune et/ou argentée varient d'environ 1100 à 2900 sur la période 1983-2007, avec un pic au milieu des années 80,90 et à nouveau en 2005-2007. Les captures déclarées culminent à la fin des années 80 et au milieu des années 90 (pic de 280 t), mais sont basses depuis 2001 (moyenne $29 \mathrm{t}$ ). Les données d'exportation suggèrent que les captures sont 4 fois plus élevées. Les débarquements d'anguilles sont portés comme captures accessoires dans diverses pêcheries maritimes le long des côtes britanniques, avec des débarquements de 2001 à 2007 variant de 0.2 à $13.7 \mathrm{t} \mathrm{par}$ an. L'évaluation de l'état des stocks repose sur les statistiques de captures et de captures par unité d'effort car il y a très de peu de suivi spécifique pour l'anguille. II y a une tendance à la baisse à la fois dans les captures de civelles enregistrées par l'Agence et dans les données nettes d'exportation. Comparer les niveaux de captures maximum de la fin des années 70 -début des années 80 avec les niveaux minimum des années 2000 montre que les captures ont décliné d'environ 75-95\%. Les tendances dans les CPUE sont similaires, au moins jusqu'en 1998. On en conclut que le recrutement actuel en civelle sur la côte ouest de la Grande-Bretagne est environ $30 \%$ du niveau antérieur aux années 80 . Les indices pour les anguilles jaunes et argentées obtenus par les exportations nettes (HMRC) ou par captures déclarées par licence vendue suggèrent tous deux que l'estimation des stocks faite à partir de ces données est $20 \%$ de l'estimation de la fin des années 80 -début des années 90 . Le modèle d'état de référence a été utilisé pour évaluer la conformité aux objectifs européens (EU règlement 1100/2007). L'évaluation se fait à l'échelle d'un district de bassin versant et dans la plupart des cas une seule rivière est utilisée pour représenter le district. L'évaluation a pour cette raison un niveau de confiance assez faible et un besoin d'amélioration est souligné dans cet article. Diverses options sont proposées pour accroître l'échappement des civelles, en particulier la pression de pêche, l'amélioration de la qualité des habitats et leur accès, le contrôle des prédateurs et l'alevinage, avec des interactions des différentes options entre rivières et bassins dépendant de priorités locales.

\section{INTRODUCTION}

The European eel, Anguilla anguilla, is widely distributed throughout European estuarine and inland waters. Estimates at the glass eel stage indicate that recruitment across Europe has fallen to below five percent of historic levels. ICES advises that the stock is outside safe biological limits and that current fisheries are not sustainable (ICES/EIFAC, 2006).

The European Commission has initiated an Eel Recovery Plan (Council Regulation No $1100 / 2007)$ to return the European eel stock to sustainable levels of adult abundance and glass eel recruitment. Each Member State is required to establish national Eel Management Plans (EMPs). These plans aim to achieve an escapement of silver eel to the spawning population that equals or exceeds a target set at $40 \%$ of the potential biomass that would be produced under conditions with no anthropogenic disturbance due to fishing, water quality or barriers to migration. Each Member State is required to:

(1) Set management targets based on the potential silver eel production under conditions of no anthropogenic mortality and high (pre-1980) levels of recruitment; 
(2) Estimate the present day silver eel escapement against this target;

(3) Implement management actions necessary to achieve or maintain compliance; and,

(4) Collect data to support steps (1) to (3) above, and to demonstrate whether compliance will be achieved in the future.

In England and Wales, eel legislation and policy is determined by the Governments, through Defra (Marine, Fisheries and Biodiversity) for England, and the Welsh Assembly Government for Wales. The Environment Agency is responsible for the management of eel stocks and associated fisheries in inland waters and in tidal waters to a distance of 6 nautical miles.

EMPs have been drawn up by the relevant UK authorities with each of the devolved administrations; Environment Agency (England and Wales), Scottish Government (Scotland), Department Culture, Arts \& Leisure for Northern Ireland, and assessed by Cefas and Defra. The aim of each EMP is to describe the nature of the eel population and fishery in the RBD, to assess whether the stock is meeting its $40 \%$ escapement target, and to present management actions that will ensure the long-term viability of the eel population.

In this paper, we describe the historic and modern fisheries for eel across England and Wales and their management, before considering how fishery and scientific data can be used to assess stock status in light of the requirements of EU regulation 1100/2007, and the management options being considered to increase silver eel output.

\section{> HISTORY OF EEL FISHERIES IN ENGLAND AND WALES}

Eel have long been exploited in England and Wales. There is evidence from the Domesday Book (Anon, 1086) of extensive eel fisheries in the Thames, which persisted up until the end of the 19th century (Naismith and Knights, 1993). Legislation to protect eel dates back many centuries. In 1553, Parliament prohibited the taking of elvers (glass eel) for 10 years, and this was made permanent in 1558. This restriction was eased in 1778, when glass eel could be taken in the Severn for consumption, but not for sale. In 1873, the Salmon Act (Section 15) introduced a close season from January 1st to June 26th which effectively banned glass eel fishing. This caused considerable local protest and, by 1876, a close season from April 26th to the end of February was introduced that enabled glass eel fishing to take place in March and April. In 1935, the close season was lifted and glass eel fishing could take place throughout the year, although the effective season ends in May (Hunt, 2007).

Simple basket-like traps or "putcheons" were used to catch yellow and silver eel for centuries, but following the introduction of the 'Dutch' fyke net from Denmark in the late 1940s, catches of eel increased to supply food markets. Local demand declined from the mid-1950s but increased rapidly from 1976 to supply Dutch and German markets for live eels. Production reached about $600 \mathrm{t}$ in 1980-1981 and remained steady for the rest of the decade, despite a continuing increase in effort. As a result, fishermen in the traditional yellow and silver eel-fishing areas from the Humber to the Thames reported a decline in individual catches and, in particular, a reduced number of large eels. As a consequence, fisheries developed in the open sea, and in the less productive waters of Wales, northwest England and Scotland (Morrice C., unpublished).

\section{> DESCRIPTION OF THE MODERN FISHERY}

All life stages of eel are exploited in England and Wales by a total of approximately 1000 licensed eel fishermen. At present, there is no legislative mechanism to limit the number of licences. The main fisheries for small eel $(<100 \mathrm{~mm}$, hereafter glass eel/elvers) are by dip-nets in estuaries draining into the Bristol Channel, in particular the Rivers Severn, Wye and Parrett, and in smaller fisheries such as that in Morecambe Bay, Cumbria (Figure 1). The main fisheries for yellow and silver eel are in southern and eastern England, with fyke nets or fixed traps (Figure 1). 


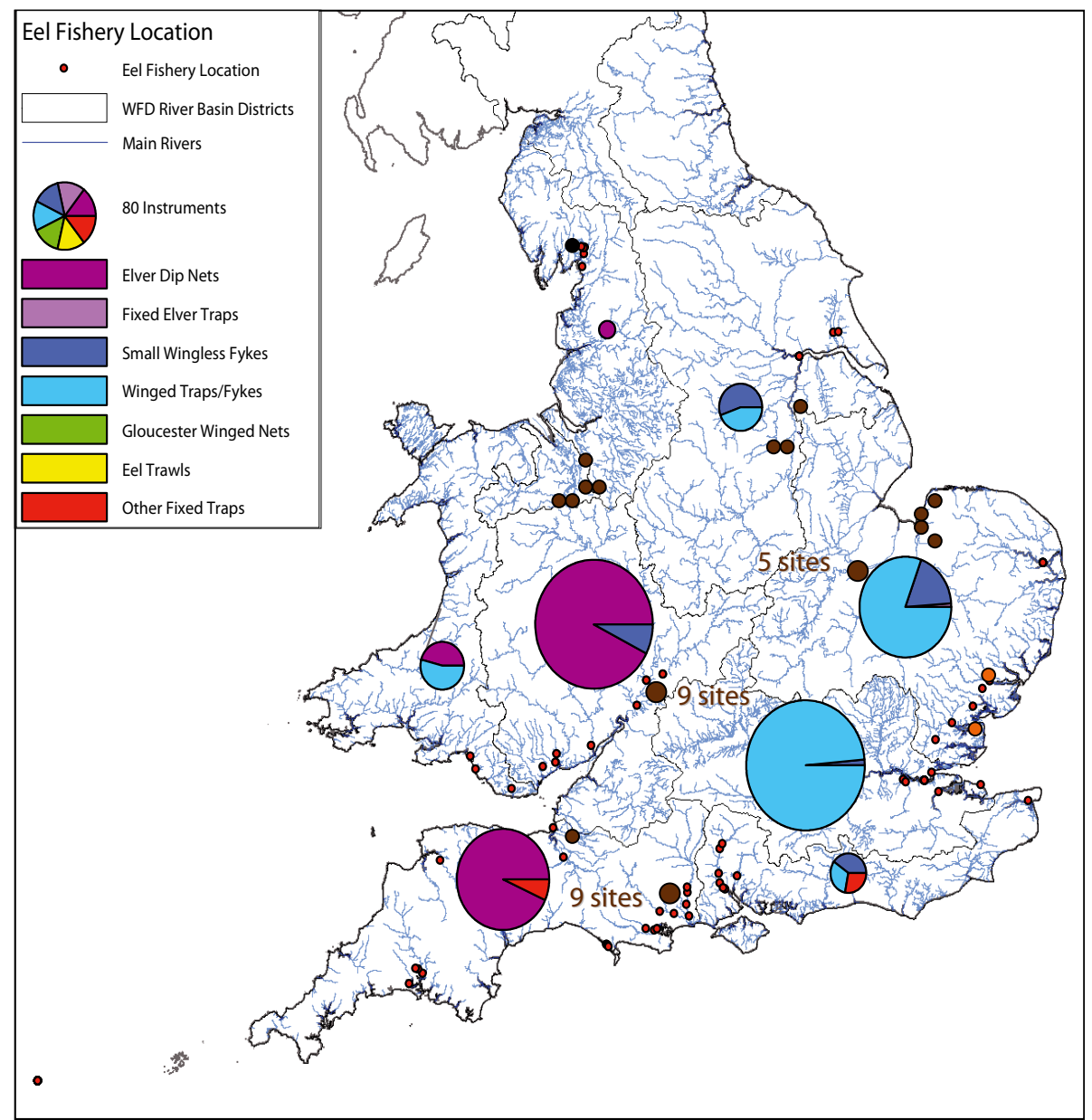

\section{Figure 1}

Location of eel fisheries in England and Wales, and sites where the Environment Agency conducts eel-specific monitoring of glass (orange circles), yellow (brown circles) and silver eel (black circles).

\section{Figure 1}

Localisation des pêcheries d'anguille en Angleterre et au pays de Galle, et sites où l'Agence de l'Environnement conduit un suivi spécifique des civelles (cercles orange), des anguilles jaunes (cercles marron) et des anguilles argentées (cercles noirs).

The Environment Agency issues annual licences for eel fishing in England and Wales. These licenses are for single EA regions (Figure 1) and are not transferable other than where estuaries are shared by more than one region (e.g. the Thames Estuary). Legislation for eel fisheries management is enacted through national and local byelaws. The National Eel Byelaws (2004) specify legal fishing gears and their method of operation, where these gears can be fished, maximum mesh sizes and minimum landing sizes.

\section{METHODS AND MATERIALS}

\section{> FISHERY DATA}

Licensed eel fishermen are obliged to report their annual catch by weight, effort in terms of days and gears fished, location and water type (coastal, river, stillwater). In addition to these 
catch returns, annual trade statistics from Her Majesty's Revenue \& Customs (HMRC) provide an alternative indication of catches. Glass eel are imported into England from France and Spain throughout the winter season (typically November to March) and subsequently reexported. By subtracting imports from exports and adding the quantities of glass eels sold for stocking in England, Wales and Northern Ireland, we arrive at a nett export proxy for the UK catch.

The HMRC data are collected for live, chilled, frozen and smoked eels, but do not differentiate between life stages. Therefore, we have estimated trade in glass eel according to month, port/airport of export (prior to 1993), country of destination and unit trade value: post-1993 glass eel value has been at least 10 times, and on some occasions up to 100 times, that of the trade in yellow/silver eels (Knights et al., 1996; Knights, 2001). This approach does not provide a definitive trade statistic, but it is anticipated that traceability measures introduced in response to the EU Regulation (1100/2007) and the Convention on Trade in Endangered Species (CITES) will provide a more direct assessment of glass eel trade from 2009 onwards.

Trends in glass eel/elver recruitment and yellow/silver eel stock status are likely to be better indicated by catch per unit of fishing effort (CPUE) than by reported catch alone. Prior to 2005, fishing effort was not a reporting requirement, but annual licence sales data from the Environment Agency and predecessor agencies provide an index from which changes in effort over time can be inferred.

Considerable year-to-year variation in catch and trade data complicate trend analysis. For the purposes of this analysis, we report moving eight-year averages for CPUE data, based on data for the year in question and the preceding seven years. Other time periods may be equally valid, but we chose the eight year period based on a seven year continental growth phase typical of eel in UK rivers, plus an additional year for silver eel-to-recruit.

UK-registered vessels fishing in marine waters occasionally land eels, and catches of Anguilla anguilla are recorded in the Fisheries Activity Database (FAD), administered by the Marine and Fisheries Agency (MFA). No information is collected on stage of eels, and catches are recorded by total weight, so neither the numbers or individual weights are available. The location of each catch is reported, but for present purposes, the data are disaggregated by ICES rectangle. Eels landed by these vessels are assumed to be bycatch of fisheries directed at other species, since catches from EA licensed fyke nets used in coastal waters should be reported to the EA. Nevertheless, temporal and spatial patterns in catches may provide clues to the distribution of eels in the ocean.

\section{> SCIENTIFIC SURVEYS}

\section{Glass eel/elvers}

There is no fishery-independent quantification of glass eel/elver recruits to UK estuaries. However, fishery-independent surveys of glass eel/elver runs commenced in 2002 and are undertaken with pass traps at two sites on the Rivers Stour and Chelmer in Essex (Figure 1). These traps are run continuously between April and July, except for periods of extreme flow events, and provide an indication of the strength of the glass eel run for that year.

\section{Yellow eel}

Multi-species electric fishing sampling has been carried out at a total of 7430 sites in England and Wales between 2001 and 2007. The monitoring programme was reviewed in 2006 , and the total number of sites to be sampled over a six year period has been reduced to 5207, of which 1115 sites are sampled annually. The majority of these annual sites $(57.5 \%)$ are sampled quantitatively, while the remainder are sampled using a semi-quantitative method (i.e. one pass fishing as opposed to three or more passes). All eel $>99 \mathrm{~mm}$ are measured to the nearest $\mathrm{mm}$ and those $\leq 99 \mathrm{~mm}$ are counted. Since 2001, quantitative 
sampling has been carried out by electric fishing at 25 sites on four rivers where eel are the target species (Figure 1). In addition comprehensive quantitative eel surveys are also available for 14 basins in England and Wales (Bark et al., 2007; Bark, Knights and Williams, unpublished data). These latter data have formed the basis of assessment modelling for EMPs in most RBDs.

\section{Silver eel}

Only one site in England and Wales has a direct means of counting silver eel escapement. Since 2000, silver eel numbers have been monitored using a resistivity counter on a weir at a single site on the River Leven in the north west of England (Figure 1). The counter is situated $3 \mathrm{~km}$ downstream of Lake Windermere, which dominates the catchment, representing $97 \%$ of the wetted area available to eel. The counter was installed to record the numbers of upstream and downstream moving salmon and sea trout, but it was noted in the 1990s that it was also counting downstream moving silver eels (Watson and McCubbing, 1997).

\section{> ASSESSMENT OF COMPLIANCE WITH EC TARGET}

Article 2.5 of the Regulation (1100/2007) sets out three approaches to assessing compliance with the target. These are:

(a) use of data collected in the most appropriate period prior to 1980, provided these are available in sufficient quantity and quality;

(b) habitat-based assessment of potential eel production, in the absence of anthropogenic mortality factors;

(c) with reference to the ecology and hydrography of similar river systems.

In the absence of widespread direct monitoring of silver eel escapement, two approaches based on yellow eel proxies have been used in England and Wales to assess compliance for this phase of the EMPs; comparison with historical data (approach (a)), or a modelling assessment (combining approaches (b) and (c)).

There are few data on yellow eel density or biomass in England and Wales prior to the start of the recruitment decline in 1983-1984, or in the absence of anthropogenic impacts such as pollution, fishing or barriers to migration (summarised by Knights et al., 2001). An example assessment is presented based on eel-specific electric fishing surveys of the River Dee, Wales in 1984, 1999, and 2002 to 2007 . Though it is accepted that the assessment does not take into account the impact of anthropogenic influences, it does compare current eel densities with those derived from glass eel recruitment prior to the recruitment collapse in 1983-1984.

More generally, the Reference Condition Model (RCM: Aprahamian et al., 2007) is being used to assess compliance for the RBDs in England and Wales and for the cross-border RBD with Scotland, and an example assessment of the River Ellen (north west) is presented here.

In many rivers of England and Wales, the density of eel naturally declines with distance upstream from the estuary (Knights et al., 2001; Ibbotson et al., 2002). Data for 12 rivers surveyed in the 1970s and early 1980s have been used to create a model that predicts the yellow eel population (in terms of densities along the river) that would have been expected before the major decline in glass eel recruitment across Europe in 1983-1984. The most significant factor explaining variation in density profile between rivers (assuming constant recruitment) was found to be river gradient (Aprahamian et al., 2007). By plotting the rate of decline in eel densities against the gradient of each river catchment, it is possible to predict the natural rate of decline for any river. This then serves as the reference model. In its basic form, the RCM assumes that the habitat available upstream of the tidal limit is uniform. However, it can be weighted according to the amount of habitat available to eel at various distances from the tidal limit, in order to assess compliance with the $40 \%$ escapement target. 


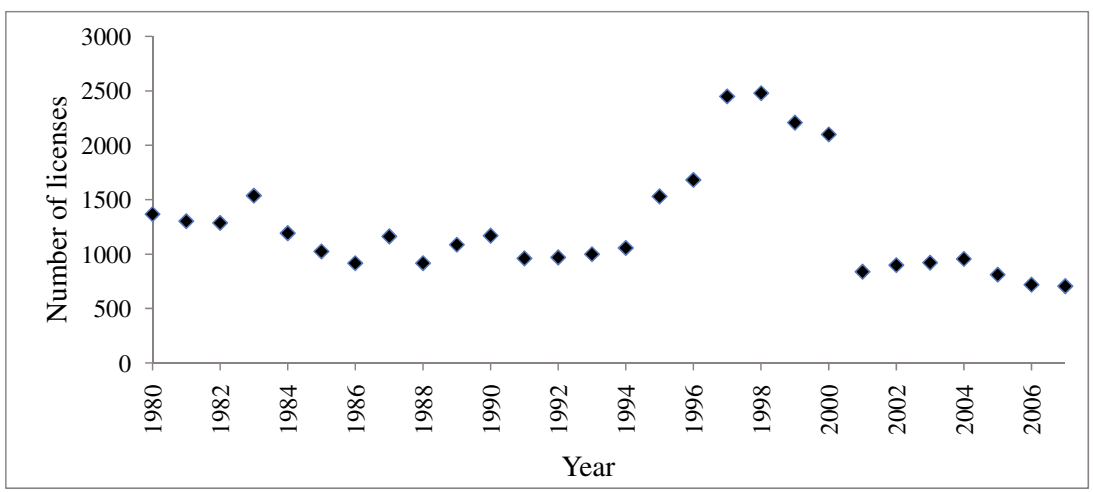

\section{Figure 2}

Numbers of elver (glass eel) dip-net licences sold by the Environment Agency and its predecessors between 1980 and 2007.

\section{Figure 2}

Nombre de licences de pêche à la civelle vendues par l'Agence de l'Environnement et ses prédécesseurs entre 1980 et 2007.

The RCM provides a surrogate assessment of yellow eel production across the basin as a proportion of an historical, reference level of production, but it does not provide estimates of the target or present-day levels of silver eel escapement. Therefore, and in the absence of robust data on the relationship between yellow and silver eel production for UK rivers, we assume a linear relationship between yellow eel and silver eel status.

\section{RESULTS}

\section{> TRENDS IN THE SMALL EEL (< 100 MM) FISHERY}

\section{Effort}

Around 1100 glass eel/elver licences (for dip nets) were sold each year from 1980 to 1994 (Figure 2). Sales increased rapidly to peak at nearly 2500 in 1998 due to substantial increases in the market value of glass eel from about $£ 100 / \mathrm{kg}$ to over $£ 250 / \mathrm{kg}$, due to extra demands from eel farms in the Far East. However, fishing activities were depressed during the 2001 Foot and Mouth Disease outbreak because of restrictions imposed on access to fishing sites, and sales have since remained around 800 per annum.

\section{Catch}

Glass eel/elver catches reported to the Environment Agency and its predecessors in the 1970 s and early 1980 s ranged between 10 and $70 \mathrm{t}$ but declined thereafter to less than $2 \mathrm{t}$ in 2001 to 2006 (Figure 3a). However, nett export data from HMRC suggests under-reporting to the Agency of between 5 and 15 times, varying between years. Neither of these datasets is particularly robust, but they do yield useful information and provide proxy estimates of recruitment and of home and international market trends (Knights, 2001). Figure 3a shows a general decreasing trend in both glass eel catches reported to the Agency and in HMRC nett export data.

Glass eel are imported into England from France and Spain throughout the winter season (typically November to March) and subsequently re-exported. According to HMRC data, 


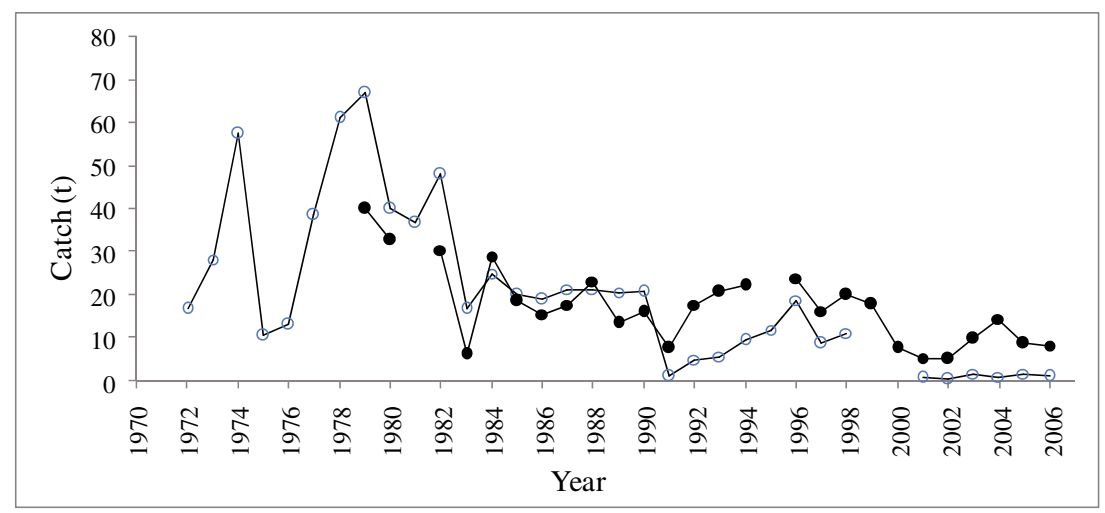

\section{Figure 3a}

Weight (t) of UK glass eel/elver catches reported to the Environment Agency or predecessors (open circles), and derived from HMRC nett export data (closed circles) from 1972 to 2006.

\section{Figure 3a}

Poids (t) des captures en Angleterre et au Pays de Galles de civelles enregistrées par l'Agence de l'Environnement et ses prédécesseurs (cercles vides), et dérivées des données d'export (cercles pleins) de 1972 à 2006.

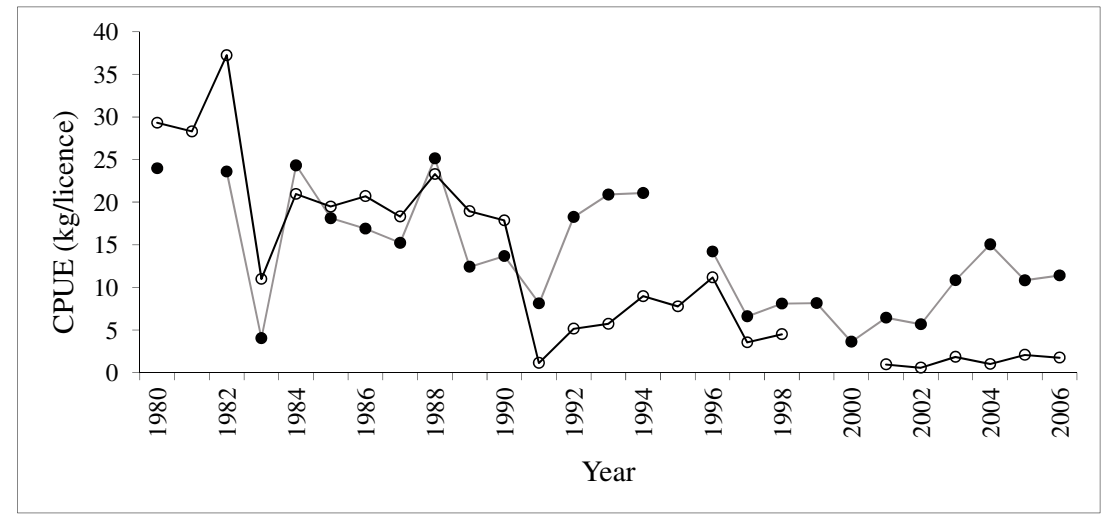

\section{Figure $3 b$}

Trends in UK glass eel/elver fishery catch per unit effort, derived from HMRC nett export weight (kg) against Environment Agency net licence sales (closed circles), and from catch reported to the EA against net licence sales (open circles) from 1980 to 2006.

\section{Figure $3 b$}

Tendances dans les captures par unité d'effort de civelles en Angleterre et au Pays de Galles, obtenues par les tonnages $(\mathrm{kg})$ d'exportation par rapport aux ventes de licences par l'Agence de l'Environnement (cercles vides) et aux captures déclarées à l'Agence de l'Environnement en fonction des ventes de licences (cercles pleins) de 1980 à 2006.

this trade comprised 41 and $56 \%$ of gross exports in 2005 and 2006, respectively. By subtracting imports from exports and adding the quantities of glass eels sold for stocking Lough Neagh in Northern Ireland, it is estimated that the glass eel catch in England and Wales averaged $10.4 \mathrm{t}$ in 2003 to 2006.

The main export markets for UK (and France and Spain) glass eel have recently been eel farms for on-growing in China, the Netherlands, Denmark and Germany, with smaller amounts going to Sweden and Greece. Relatively small amounts (up to a few hundred $\mathrm{kg}$ ) have also gone to countries such Latvia, Lithuania and Poland. The proportion of trade 


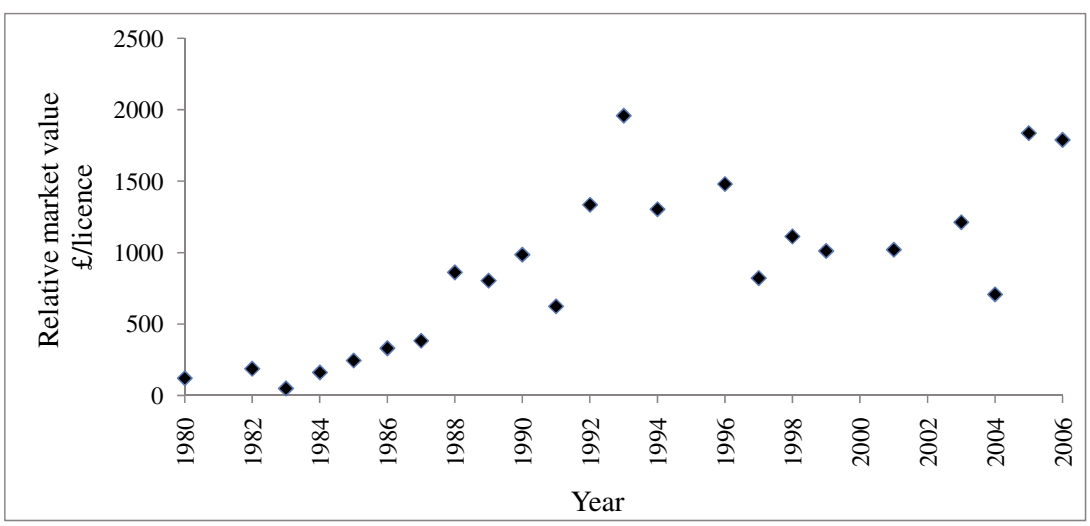

\section{Figure 4}

Trends in annual total value (£) of UK glass eel/elver trade (HMRC data) per licence sold to the EA or its predecessors from 1980 to 2006.

\section{Figure 4}

Tendances dans la valeur totale annuelle ( $£$ ) des échanges en civelles en Grande-Bretagne (données HMRC) par licence vendue par l'Agence de l'Environnement et ses prédécesseurs entre 1980 et 2007.

to the Far East varies considerably from year to year, for example accounting for about $45 \%$ of total exports in 2005 and 2007, and around 5\% in 2006.

\section{Catch per unit effort}

Trends in CPUE (kg/net licence sales) derived from reported catch or nett exports are similar (Figure 3b), at least to 1998 (correlation coefficient: 0.62). Both indices show declining trends throughout the 1980s and 1990s, but increases from 2002. Trend analysis of 8-year moving averages suggests that while CPUE based on catches reported to the Environment Agency has declined by more than $95 \%$, that based on nett exports has only declined by about $75 \%$.

The value of the annual glass eel/elver nett export trade has varied from $£ 700000$ to nearly $£ 2$ million since 2003. Though reported catch, nett exports and catch per licensed net have declined since the 1980s, this has been to some extent offset by the increase in the unit value of glass eel, such that the value of an individual fisherman's catch ( $£$ per licence) has increased (Figure 4).

\section{> YELLOW AND SILVER EEL FISHERY}

\section{Effort}

Similarly, market forces are thought to account for variation in licence sales for yellow and silver eel fisheries. Environment Agency sales of yellow and silver eel licences (combined) have varied from around 1100 to 2900 over the period 1983-2007, with highest sales in the mid-1980s, mid-1990s and again in 2005 to 2007 (mean 2622) (Figure 5).

\section{Catches}

Annual catch returns to the Environment Agency for yellow and silver eel fisheries (combined) have averaged $25.8 \mathrm{t}$ over the period 2003-2006 and have been at a low level since 2001 compared to the late 1980s and mid 1990s (Figure 6a). The annual HMRC nett export of yellow and silver eels has averaged 125.6 t over the period 2003-2006, and show the same trends. As with the glass eel/elver reports, these data suggest that the Agency catch returns are likely underestimates (by $\sim 6$ times) of the true catch. 


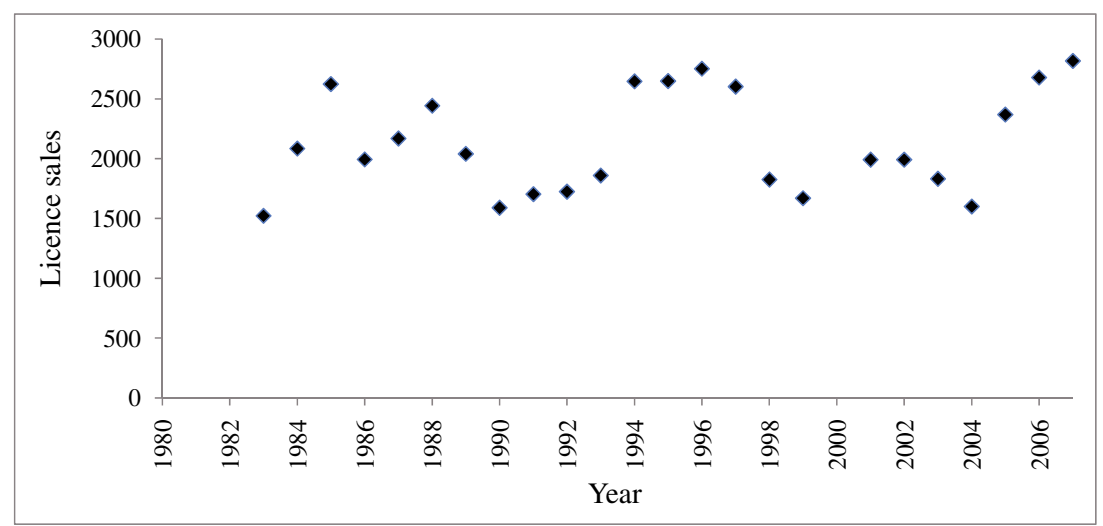

\section{Figure 5}

Numbers of yellow and silver eel licences (combined) sold by the Environment Agency and its predecessors between 1983 and 2007.

\section{Figure 5}

Nombre de licences de pêche aux anguilles jaunes et argentées vendues par l'Agence de l'Environnement et ses prédécesseurs entre 1983 et 2007.

Again, estimating CPUE for English and Welsh yellow and silver eel fisheries is problematic, given concerns regarding under-reporting, but indices derived from HMRC nett exports or reported catches per licence sold both suggest relatively consistent CPUEs in the late 1980s to late 1990 s, with a decline of about $80 \%$ from then onwards (Figure 6b).

The annual nett value of the yellow and silver eel export trade, based on HMRC data, has varied from about $£ 200000$ to $£ 300000$ since 2003, after declining from between $£ 1$ and $£ 3$ million per year in the late 1980s to 1990s (Figure 7). The HMRC-derived price per $\mathrm{kg}$ peaked in the late 1980s and early 1990s, but has typically varied between $£ 3$ and £6 for most of the last three decades, with the exception of 2004 and 2005 when it fell below £2 (Figure 7). In addition to the trade in UK-sourced eel, significant quantities of yellow and silver eel are traded through the UK from around the world, presumably of several Anguilla spp. In comparison to the recent UK average annual catch of $\sim 126 \mathrm{t}, 180 \mathrm{t}$ of frozen eel and $23 \mathrm{t}$ of smoked eel were imported to the UK in 2007. China (89 t) and New Zealand (76 t) were the main sources of frozen eel, with others from Germany, the Netherlands and Malaysia. Germany was the main supplier of smoked eels (22 $t)$, with the remainder from Denmark, France, Spain, New Zealand and Poland.

\section{> MARINE FISHERY}

UK-registered vessels landed a total of $30.6 \mathrm{t}$ of eel between 2001 and 2007. Annual landings ranged from 0.2 to $13.7 \mathrm{t}$, with landings in 2001 to 2003 much higher than in more recent years (Table I). The majority of these marine catches of eels reported from UK waters have been taken along the south coast of England and in the Irish Sea (Figure 8). Most eel were reported caught in otter trawls $(17042 \mathrm{~kg})$, fyke nets $(7592 \mathrm{~kg})$ or long lines $(3187 \mathrm{~kg})$ (Table II).

\section{> SCIENTIFIC SURVEYS}

\section{Glass eel}

Annual catches of glass eel and pigmented eel are reported in Table III, for the Chelmer from 2002-2006, and for the Stour from 2002 to 2005. The Stour trap was not run continuously 


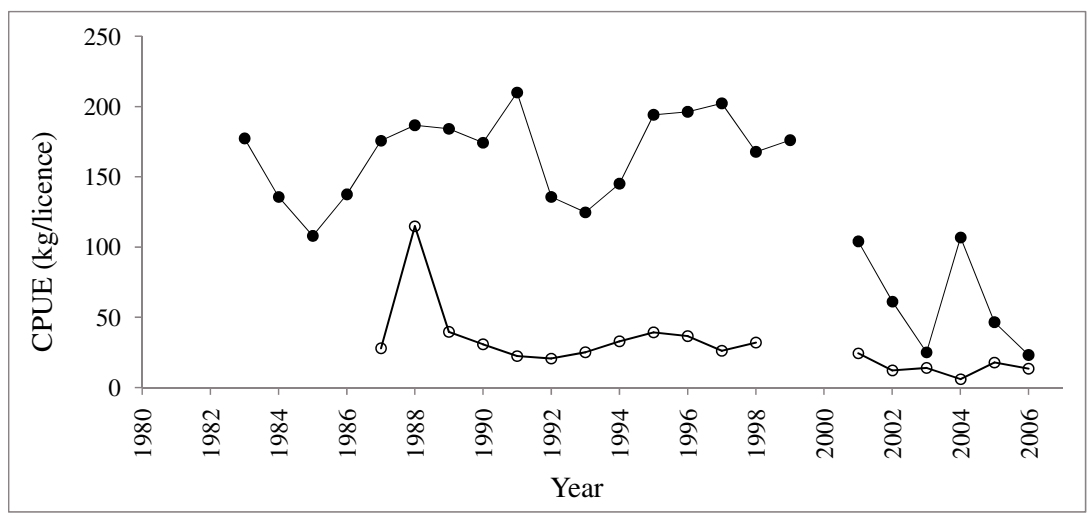

\section{Figure 6a}

Trends in yellow/silver eel catches reported to the Environment Agency in $t$ (open circles), and derived from HMRC nett export data (closed circles) from 1979 to 2006.

\section{Figure 6a}

Tendances dans les captures d'anguilles jaunes et argentées en tonnes (cercles vides) enregistrées par l'Agence de l'Environnement et dérivées des données d'exportation (cercles pleins) de 1979 à 2006.

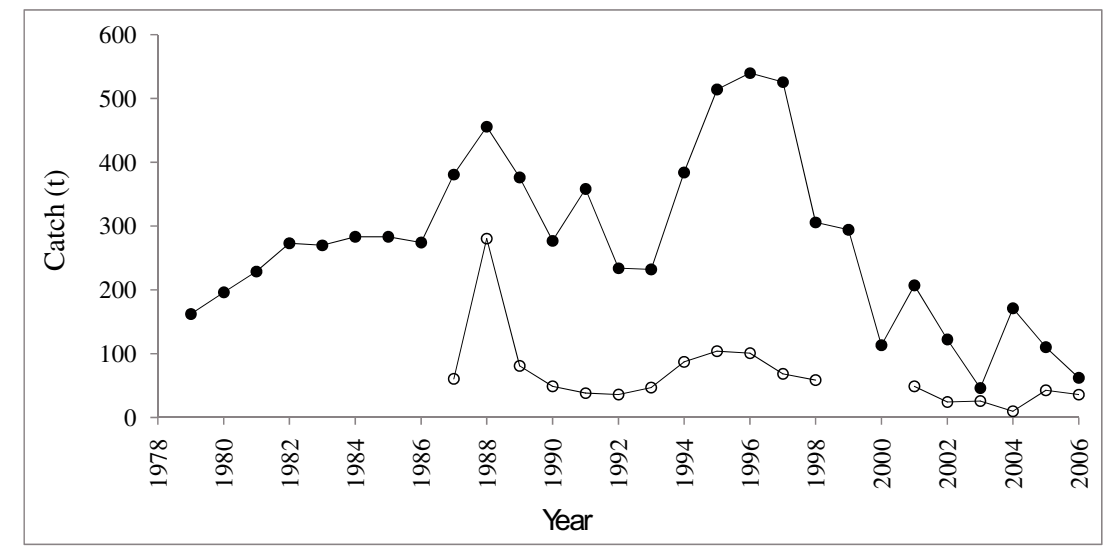

\section{Figure $6 b$}

Trends in England and Wales yellow/silver eel fishery catch per unit effort, derived from HMRC nett export weight $(\mathrm{kg})$ against Environment Agency net licence sales (closed circles), and from catch reported to the EA against net licence sales (open circles) from 1983 to 2006. Note that licenses are required for each fixed trap and for each net-end, and therefore the number sold is considerably greater than the number of 'licensed' fishermen.

\section{Figure $6 b$}

Tendances en Angleterre et au Pays de Galles des captures par unité d'effort, des anguilles jaunes ou argentées, obtenues à partir des données d'export $(\mathrm{kg})$ par rapport aux ventes de licences par l'Agence de l'Environnement (cercles pleins) et aux captures enregistrées par l'Agence de l'Environnement (cercles vides) par rapport aux ventes de licences de 1983 à 2006. Noter qu'une licence est nécessaire pour chaque trappe et filet et que par conséquent le nombre vendu est nettement supérieur au nombre de pêcheurs licenciés.

in 2006 due to low flows. On the occasions the trap could be run, no glass eels or elvers were caught and none were observed on the weir as in previous years. Although it is not practical to calculate trends in glass eel runs over such a short time, it is worth noting that, apart from moderate increases in catch in 2006 for the Chelmer and in 2004 for the Stour, there have been very low numbers of glass eels/elvers caught since an initial peak in catch for both traps in 2002. 


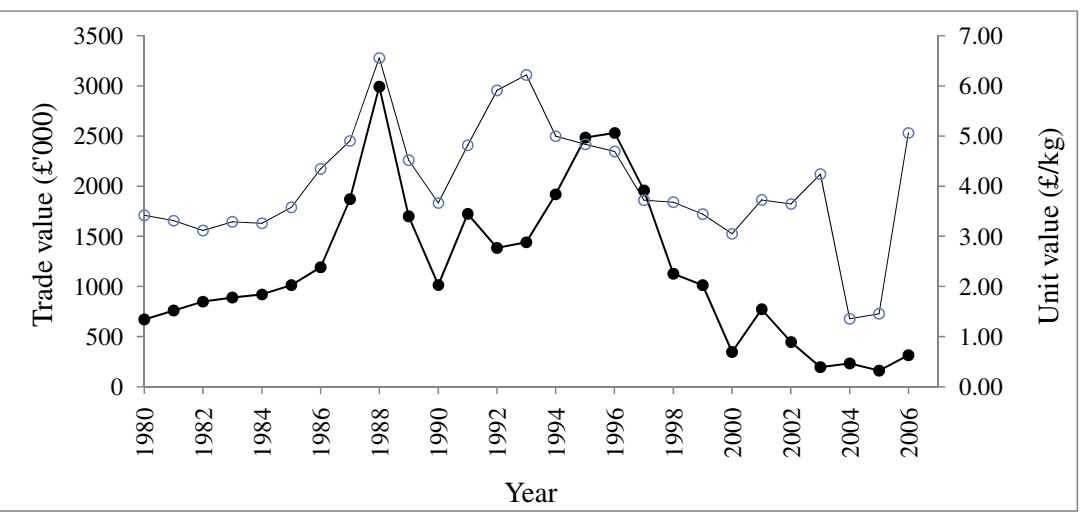

\section{Figure 7}

Trends in annual total value (£) of UK yellow and silver eel trade from HMRC nett export data (closed circles), and in value of the catch $(£ / \mathrm{kg})$ derived from HMRC nett export data (open circles) from 1980 to 2006.

\section{Figure 7}

Tendances dans la valeur annuelle (£) des échanges en anguilles jaunes ou argentées en GrandeBretagne à partir de données d'export (cercles pleins) et en valeur des captures $(£ / \mathrm{kg})$ estimée à partir de données d'export (cercles vides) de 1980 à 2006.

\section{Table I}

Monthly weight of eel reported landed by UK-registered vessels during 2001 to 2007. Data provided by the Marine and Fisheries Agency. Note that landings are not distinguished as target or bycatch in these data.

Tableau I

Déclarations mensuelles pondérales d'anguilles débarquées. Données fournies par l'Agence de la mer et des pêcheries. Noter que ces données ne se distinguent pas en captures ciblées ou accessoires.

\begin{tabular}{|l|c|c|c|c|c|c|c|c|}
\hline Month & 2001 & 2002 & 2003 & 2004 & 2005 & 2006 & 2007 & Total weight (kg) \\
\hline January & 500 & 5 & & 379 & 1 & 30 & & 915 \\
\hline February & & 17 & 346 & & 8 & 1 & 30 & 402 \\
\hline March & & 1 & & 4 & 1 & & 36 & 42 \\
\hline April & 211 & 157 & 1997 & 52 & 109 & 6 & 79 & 2611 \\
\hline May & 499 & 48 & 1878 & 2 & 6 & 4 & 206 & 2643 \\
\hline June & 883 & 782 & 2793 & 143 & 1133 & 34 & 313 & 6081 \\
\hline July & 1229 & 934 & 1360 & 265 & 3 & 12 & 170 & 3973 \\
\hline August & 964 & 778 & 1137 & 52 & 120 & 10 & 162 & 3223 \\
\hline September & 1187 & 645 & 1696 & 624 & 50 & 68 & 9 & 4279 \\
\hline October & 242 & 606 & 1169 & 533 & 46 & 13 & 1 & 2610 \\
\hline November & 144 & 712 & 970 & 302 & 7 & 38 & 3 & 2176 \\
\hline December & 590 & 508 & 351 & 190 & 4 & 3 & 21 & 1667 \\
\hline Totals & 6449 & 5193 & 13697 & 2546 & 1488 & 219 & 1030 & \\
\hline
\end{tabular}




\section{Table II}

Landings reported as Anguilla anguilla by UK-registered vessels fishing in marine waters: summary of catches by gear for the period 2001 to 2007. Data provided by the Marine and Fisheries Agency.

\section{Tableau II}

Débarquements déclarés comme Anguilla anguilla par les bateaux enregistrés en Grande-Bretagne pêchant en mer : données des captures par engin de pêche de 2001 à 2007. Données de l'Agence pour la mer et les pêcheries.

\begin{tabular}{|c|c|c|c|c|}
\hline \multicolumn{2}{|l|}{ Methods } & \multicolumn{3}{|c|}{ Catch (kg) } \\
\hline & & \multicolumn{2}{|c|}{ Daily } & \multirow[t]{2}{*}{ Total } \\
\hline & & $\max$ & mean & \\
\hline Dredge & Unspecified dredge & 21 & 7 & 134 \\
\hline \multirow[t]{8}{*}{ Trawl } & Otter trawl & 457 & 138 & 1114 \\
\hline & Pair trawl & & & 30 \\
\hline & Beam trawl & & & 44 \\
\hline & Nephrops otter trawl & 30 & 13 & 80 \\
\hline & Twin Nephrops otter trawl & 120 & 75 & 450 \\
\hline & Unspecified otter trawl & 1013 & 76 & 15395 \\
\hline & Twin otter trawl & & & 3 \\
\hline & Mid-water pair trawl & 150 & 100 & 400 \\
\hline \multirow[t]{2}{*}{ Hooks and lines } & Set long-lines & 807 & 49 & 3187 \\
\hline & Hand and Pole lines & 25 & 6 & 138 \\
\hline \multirow[t]{6}{*}{ Traps } & Fyke nets & 369 & 138 & 7592 \\
\hline & Pots and traps & & & 6 \\
\hline & Mixed pots & 77 & 19 & 868 \\
\hline & Parlour pots & & & 3 \\
\hline & Top opening pots & & & 28 \\
\hline & Whelk pots & & & 23 \\
\hline \multirow[t]{3}{*}{ Nets } & Trammel net & 62 & 21 & 144 \\
\hline & Drift net & 53 & 6 & 298 \\
\hline & Unspecified gill net & 25 & 4 & 185 \\
\hline Seines & Scottish fly seine & 250 & 167 & 500 \\
\hline
\end{tabular}

\section{Yellow eel}

Multi-species electric fishing sampling at a total of 7430 sites in England and Wales between 2001 and 2007, inclusive, show eel to be present in nearly all river systems (Figure 9). There are some areas where eels are scarce or absent, particularly the upper reaches of rivers, though some lower reaches of rivers appear devoid of eel whilst the species is present further upstream. Rather than representing true absences, this may result from different survey techniques being utilized across a catchment, and/or the difficulties in catching and surveying eel in deeper parts of rivers. Eel were present in $43-51 \%$ of the survey samples during this period. Analysis of trends in the presence/absence, densities and length structure 


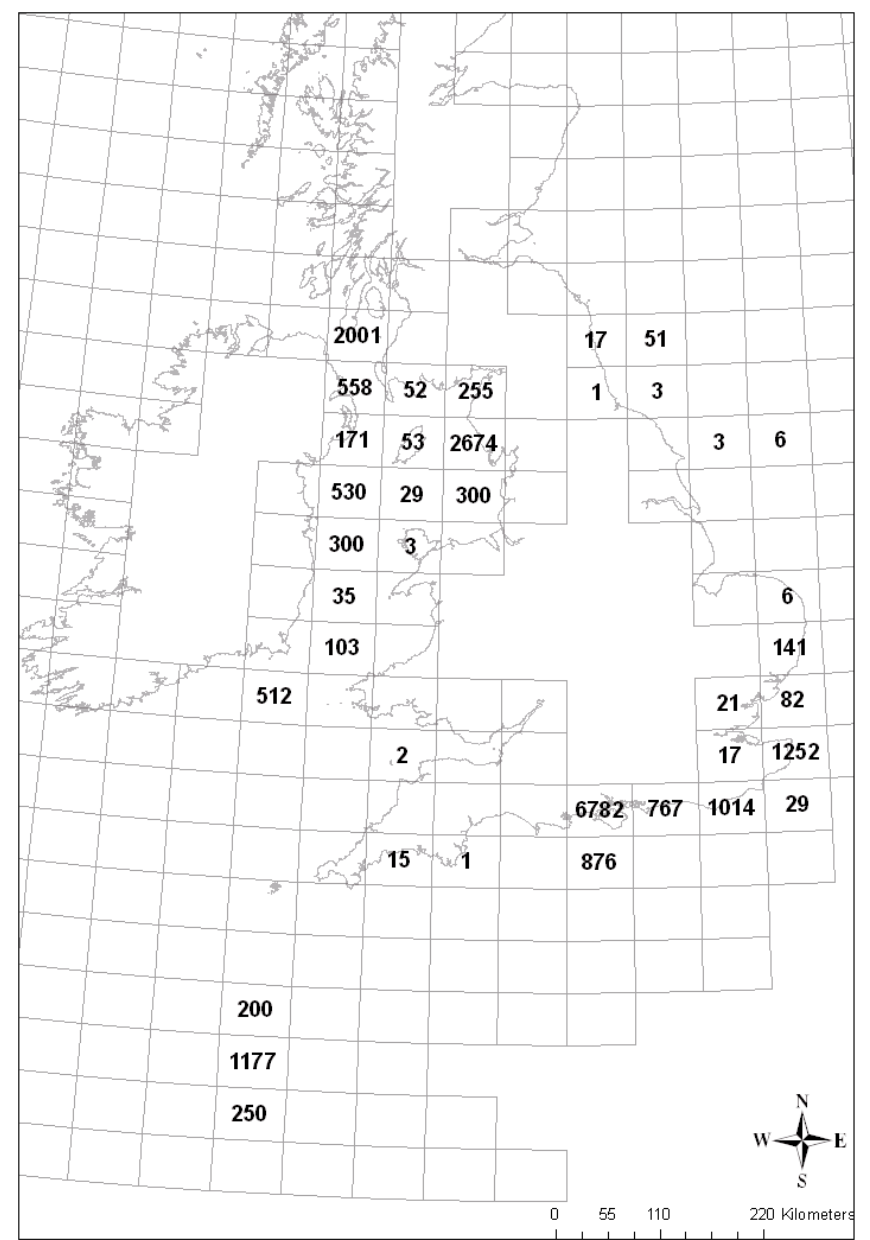

\section{Figure 8}

Total weight $(\mathrm{kg})$ of eel landed by UK-registered fishing vessels operating in marine waters between 2001 and 2007. Data provided by the Marine and Fisheries Agency.

\section{Figure 8}

Tonnage total $(\mathrm{kg})$ d'anguille débarqué par les bateaux pêchant en mer enregistrés en GrandeBretagne de 2001 à 2007. Données de l'Agence pour la mer et les pêcheries.

are being conducted to support stock assessments during the initial phase of the implementation of EMPs.

\section{Silver eel}

In 2000, and from 2002 onwards, silver eel numbers have been monitored using a resistivity counter on a weir at a single site on the River Leven in the north west of England. Downstream eel counts varied between 98 and 1090 during the period (Table IV), but these should be considered as minima since counter efficiency has not been established, and technical difficulties in 2004, 2005 and 2006 prevented a full count in each of these years.

\section{> ASSESSING COMPLIANCE WITH EC TARGET}

\section{Historical comparison (an example from the River Dee)}

Eel-specific electric fishing data for the Welsh Dee have been gathered over a number of years: in 1984 eight sites were surveyed, and these were repeated in 1999. In each year 
Table III

Counts of glass eel and elvers in upstream traps on Anglian rivers. n.d.: no data.

Tableau III

Comptages de civelles et jeunes anguilles dans les trappes de montaison sur les rivières Anglian. n.d. : aucune donnée.

\begin{tabular}{|c|c|c|c|c|c|c|}
\hline Stour/glass & April & May & June & July & August & Total \\
\hline 2002 & 1862 & 442 & 9280 & 114 & 5 & 11703 \\
\hline 2003 & & 165 & 1302 & & & 1467 \\
\hline 2004 & 51 & 1965 & 4500 & 210 & & 6726 \\
\hline 2005 & 58 & 205 & 295 & & & 558 \\
\hline 2006 & & & & & & n.d. \\
\hline \multicolumn{7}{|c|}{ Stour/pigmented } \\
\hline 2002 & 106 & 21 & 1020 & 70 & 10 & 1227 \\
\hline 2003 & & 43 & 0 & & & 43 \\
\hline 2004 & 2 & 135 & 160 & 3 & & 300 \\
\hline 2005 & 6 & 33 & 28 & & & 67 \\
\hline 2006 & & & & & & n.d. \\
\hline \multicolumn{7}{|c|}{ Chelmer/glass } \\
\hline 2002 & 1104 & 2505 & 205 & 139 & 43 & 3996 \\
\hline 2003 & & 12 & 27 & 39 & & 78 \\
\hline 2004 & 32 & 0 & 6 & 15 & & 53 \\
\hline 2005 & 20 & 53 & 65 & 0 & & 138 \\
\hline 2006 & & & & & & 1224 \\
\hline \multicolumn{7}{|c|}{ Chelmer/pigmented } \\
\hline 2002 & 6 & 33 & 11 & 419 & 619 & 1088 \\
\hline 2003 & & 1 & 23 & 17 & & 41 \\
\hline 2004 & 0 & 0 & 0 & 7 & & 7 \\
\hline 2005 & 144 & 0 & 130 & 15 & & 289 \\
\hline 2006 & & & & & & 8 \\
\hline
\end{tabular}

since 2002, four of these sites have been resurveyed, and one new site fished, data are presently available to 2007 . A comparison of the rate of decline with distance from the tidal limit between these curves provides a direct measure of the change in eel population through time (Figure 10). When those data from the 2007 surveys, which showed the lowest densities, are compared with the 1984 curve, this suggests that the potential production of silver eels from the Dee in 2007 could be $30 \%$ of the 1984 population.

\section{Modelling comparison (an example using the River Ellen)}

Data from the 2004 electric fishing surveys of the River Ellen (Bark, Knights and Williams, unpublished data) were applied to the Reference Condition Model to assess compliance with pristine conditions (Figure 11). Comparison of the 2004 situation (area under the curve) 


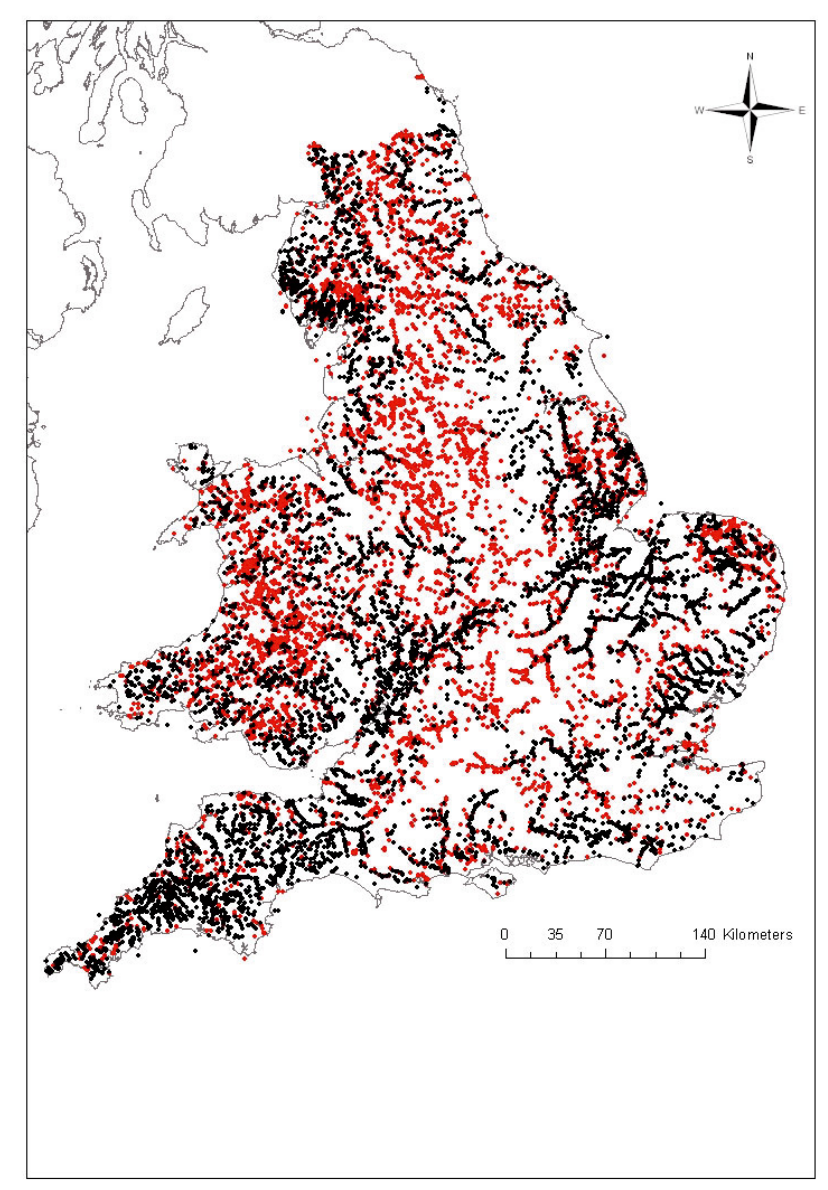

\section{Figure 9}

Distribution of eel around England and Wales based on presence (red circles) or absence (black circles) of eel in Environment Agency multi-species surveys conducted during 2001 to 2007.

\section{Figure 9}

Distribution de l'anguille en Angleterre et au Pays de Galles en présence (cercles rouges) et absence (cercles noirs) dans les suivis pluri-spécifiques conduits par l'Agence de l'Environnement de 2001 à 2007.

\section{Table IV}

Downstream counts of migrating silver eels leaving the River Leven, northwest England, based on resistivity counter records.

\section{Tableau IV}

Comptages d'anguilles argentées dévalant en rivière Leven, nord-ouest de l'Angleterre, enregistrements de compteur à résistivité.

\begin{tabular}{|c|c|}
\hline 2000 & 704 \\
\hline 2001 & No data \\
\hline 2002 & 878 \\
\hline 2003 & 1090 \\
\hline 2004 & 98 \\
\hline 2005 & 181 \\
\hline 2006 & 358 \\
\hline 2007 & 962 \\
\hline
\end{tabular}




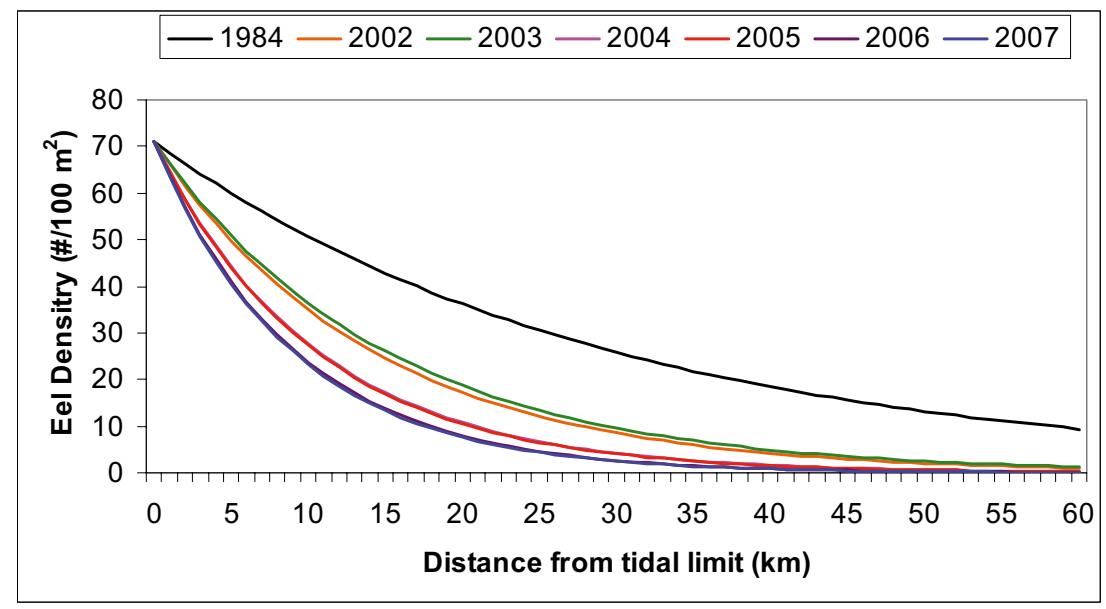

Figure 10

The observed rates of decline in eel density (electric fishing surveys) with distance upstream from the tidal limit of the River Dee, Wales, for 1984 and 2002 to 2007.

\section{Figure 10}

Taux observés de décroissance des densités d'anguilles (suivi par pêche électrique) en fonction de la distance à la mer dans la rivière Dee, Pays de Galles, en 1984 et de 2002 à 2007.

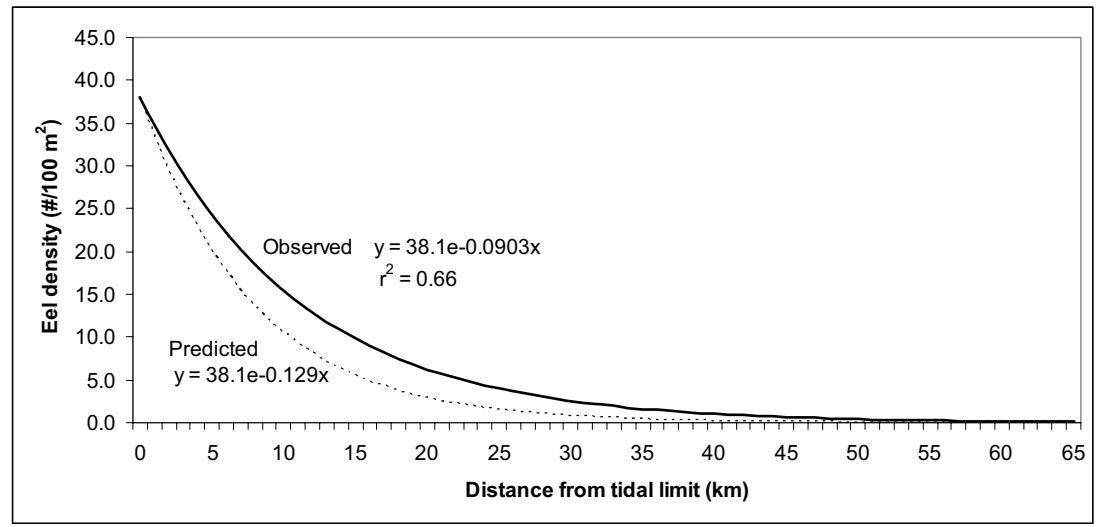

\section{Figure 11}

The predicted (RCM: dotted line) and observed (electrofishing surveys: solid line) rates of decline in eel density with distance from the tide for the River Ellen, Northwest England.

\section{Figure 11}

Taux prédits ( RCM : ligne pointillée) et observés (pêches électriques : trait plein) de décroissance des densités d'anguilles en fonction de la distance à la mer dans la rivière Ellen, nord-ouest de l'Angleterre.

with that estimated by the RCM suggests that the potential production of silver eels from the Ellen exceeded that under reference ("pristine") conditions. The conclusion from this is that the Ellen meets the $40 \%$ escapement target.

\section{Overall assessment of compliance}

In accordance with the recommendations set out in the Regulation, River Basin Districts (RBDs) developed for the Water Framework Directive (WFD) have been set as management units. An estimate of compliance for each of the RBDs is shown in Table V. 
Table $V$

An estimate of compliance for each of the RBDs.

Tableau V

An estimate of compliance for each of the RBDs.

\begin{tabular}{|l|c|c|c|c|}
\hline $\begin{array}{l}\text { River Basin } \\
\text { District }\end{array}$ & $\begin{array}{c}\text { River(s) used to } \\
\text { assess compliance }\end{array}$ & $\begin{array}{c}\text { Percentage } \\
\text { compliance }\end{array}$ & Pass/Fail & $\begin{array}{c}\text { Method used to } \\
\text { assess compliance }\end{array}$ \\
\hline Northumbria & Blyth & 61 & Pass & RCM model \\
\hline Humber & Hull & 25 & Fail & RCM model \\
\cline { 2 - 5 } & Colne & 82 & Pass & RCM model \\
\cline { 2 - 5 } & Blackwater & 54 & Pass & RCM model \\
\cline { 2 - 5 } Thames & Medway & 100 & Pass & Historic analysis \\
\hline South East & Adur & 65 & Pass & Historic analysis \\
\hline South West & Gara & 32 & Pass & RCM model \\
\hline Severn & Severn & 34 & Fail & RCM model \\
\hline West Wales & Wnion & $>100$ & Pass & RCM model \\
\hline Dee & Dee & 30 & Fail & Historic analysis \\
\hline North West & Ellen & $>100$ & Pass & RCM model \\
\cline { 2 - 5 } & Leven & 62 & Pass & Historic analysis \\
\hline Solway Tweed & Sark & $>100$ & Pass & RCM model \\
\hline
\end{tabular}

\section{DISCUSSION}

\section{> STOCK STATUS}

Assessment of stock status is based mainly on catch and catch per unit effort data as there has been little fishery independent survey of eel. There has been a general decreasing trend in both glass eel catches reported to the Agency and in HMRC nett export data. Considerable between-year variations in these data preclude meaningful analyses based on running period means. However, simply comparing maximum catch levels in the late 1970s/early 1980s with minimum levels in the 2000s suggests that the catch reported to the Agency has declined by more than $95 \%$ and the HMRC nett exports by $75 \%$. Trends in CPUE (as $\mathrm{kg} / \mathrm{net}$ licence sales) derived from reported catch or nett exports are similar, at least until 1998. Both indices show declining trends throughout the 1980s and 1990s, similar in magnitude to those of reported catch and HMRC nett exports. In contrast, both indices show increases from 2002, by about three times to 2006. It is concluded that current glass eel recruitment to the western coast of the UK is approximately $30 \%$ of the pre-1980 level of recruitment.

Prior to 2005, fishermen licensed to fish for yellow and silver eel were not required to separately report catches of eel by life stage. As such, most fishery data are for combined catches of both stages. Annual catch returns to the Environment Agency for yellow and silver eel fisheries (combined) have averaged $25.8 \mathrm{t}$ over the period 2003-2007, and have been at a low level since 2001 compared to the late 1980s and mid 1990s. The annual HMRC nett export of yellow and silver eels averaged $125.6 \mathrm{t}$ over the period 2003-2007, and shows 
the same trends. As with the glass eel/elver reports, these data suggest that the Agency catch returns are likely underestimates of the true catch.

As with glass eel/elver data, estimating CPUE for English and Welsh yellow and silver eel fisheries is problematic because of concerns about under-reporting, but indices derived from HMRC nett exports or reported catches per licence sold both suggest that the current estimate of stocks derived from these data is $20 \%$ those of the late 1980 s and mid 1990 s.

Eel are landed by marine vessels throughout the year, but the ad hoc nature of these catch data and variation in monthly catch across years mean that there is little to be learned from seasonal analyses of the complete dataset. Targeted analysis of catch data from particular vessels, or groups of vessels operating the same gear in different years may yield more worthwhile results and merit further study.

The information reported from the eel fishery in England and Wales is of poor quality and, although a new catch return system was imposed in 2005, many catch reports still are not allocated to any particular river or RBD. Clearly, the under-reporting of catches must be addressed and the quality of data improved.

\section{> ASSESSING COMPLIANCE WITH EC TARGET}

As the EU target has been defined in terms of silver eel weight, the most direct compliance assessment would be allowed by the capture and weighing of emigrating silver eels. However, few silver eel fisheries operate in England and Wales, and the installation and operation of new traps is restricted financially. In contrast, yellow eels are captured during multi-species electric fishing surveys. These survey results are useful in examining the distribution of eel and providing qualitative indices of relative abundance. An eel-specific focus is considered essential for robust local population estimates, since comparison between the results of multispecies and eel-specific surveys suggests the former may underestimate eel densities by a factor of 3 to 5 (Knights et al., 2001). Therefore, since 2001, quantitative sampling targeted at eel has been conducted at 25 sites across four rivers. The aim is to expand these types of survey, with the data feeding into models which can be used to better assess stocks in relation to the EC target. Though the elver traps only provide semi-quantitative data, it is important to continue this type of monitoring to provide data on trends over time.

In addition to the extra level of eel specific monitoring, further work is on-going to improve our use of multi-species survey data. Interpretation of the eel component from the routine multi-species electric fishing surveys is presently under development and relationships between eel population data and environmental data are being explored. The aim is to compare the observed density with an expected density derived (at present) from river width, altitude and a spatial component based on rivers that have no anthropogenic impacts on eel populations (Wyatt and Sedgwick, unpublished). The spatial component is to take into account the fact that populations on the east coast are further away from the main recruitment pathways when compared to the west coast and thus naturally have a lower density (Knights et al., 2001). The expected abundance effectively reflects habitat suitability of the particular stretch of river where surveys were conducted. The Environmental Quality Ratio (EQR) (i.e. the observed density in relation to the expected density), for each site can then be determined and used as an index of stock status.

For the majority of the EMPs, the RCM has been used to assess compliance. For most of the EMPs, data on yellow eel from a single river have been used to represent the whole RBD. The assessment therefore has a low level of confidence attached to it and data from other river systems across the RBDs are needed to improve the assessment of compliance.

\section{> FISHERIES MANAGEMENT OPTIONS TO ACHIEVE COMPLIANCE}

There are a number of options to increase silver eel escapement, but here we focus on the potential across England and Wales for reductions in fishing pressure, improving access and habitat quality, reducing the impacts of entrainment, controlling predators and stocking, with the interplay of options varying between rivers and basins depending on local priorities. 


\section{Reduction in fishery pressure}

It is essential that exploitation is sustainable against the management target of $40 \%$ silver eel escapement. However, given the concerns about the quality of catch data available to managers, and until more detailed information is gathered on stocks and the fishery to inform a better assessment of the eel fishery, the precautionary approach should be to hold the fishery within its existing limits by not allowing any increases in the number of instruments or the range of where they are currently operated. At present, the Environment Agency can introduce a byelaw to limit the fishery by reducing season length, but it cannot refuse a licence or restrict where fishers can and cannot fish within the existing boundaries. Further powers to limit the number of fishermen are currently being sought through the Marine Bill.

\section{Improving access and habitat quality}

There is perceived to have been a loss of habitat over the last half-century in many parts of England and Wales, particularly in the lower reaches of river basins, which may have resulted in a reduction in eel production. The Environment Agency will take every opportunity to improve habitat and passage for fish (including eels) through its own internal work programme and its consenting of work by others. One relatively simple and quick improvement might be to influence the lowland ditch maintenance programme so that eel habitat is maintained or improved. This may require fish passes so that eels have access to these areas, but the benefits for the eel stock could be significant.

The Environment Agency measures water quality using the General Quality Assessment (GQA) system, which assesses stretches of freshwater in terms of their chemical, biological and nutrient levels. Some RBDs have been impacted by eutrophication, but nutrient loading from point sources such as industry and sewage treatment works has been greatly reduced in the last 20 years. Pollution is still an issue, and persistent chemicals from a range of sources are known to impact on fish stocks (Foster and Block, 2006).

Eels contain a high level of fat in their muscles and, as a result, readily accumulate fatsoluble chemicals such as organochlorines. Recent research reviewed by ICES/EIFAC (2006) shows that the quality of the silver eels escaping from the continent might be seriously impaired by levels of contaminants. There are no national field sampling programmes that address this issue in England and Wales, but they may be implemented in future, either through the EMPs or the WFD.

\section{Entrainment and hydropower}

Entrainment and impingement of eel can be a major cause of mortality at abstraction points, cooling water intakes and tidal power plants. Eels have considerably higher mortality rates at hydropower stations than other fish: injury from turbines ranging between 15 and $38 \%$ (reviewed by ICES/EIFAC, 2007). Although all stages have been recorded at many water intakes in England and Wales, there has been no concerted effort to quantify the impact of entrainment on stocks at a Regional or National level (Environment Agency, 2005). In recent years, there has been increasing interest in low head hydropower on rivers in England and Wales. Studies within the first phase of EMP implementation will identify where significant mortalities due to entrainment may exist and how these might be reduced.

\section{Stocking of glass eel}

There is a general assumption that stocking increases the overall production of eel in a river system that is currently not fulfilling its potential, due to increased growth rate and lower mortality of eels stocked into relatively productive but low density areas. There is evidence from the River Severn that glass eel stocked in the middle reaches did grow substantially 
faster than those in the lower reaches (Aprahamian, 1987). The RCM is presently being used to assess the number of glass eel needed to be stocked to ensure compliance, assuming a survival rate of $15 \%$ from glass to silver eel (ICES/EIFAC, 2007). The main practical issue regarding the stocking of eel is the cost of source eels ( $£ 375 / \mathrm{kg}$ in 2008), but a stocking plan will be developed within each EMP.

\section{Predator control}

Piscivorous birds in the UK are protected under the Wildlife and Countryside Act 1981, which implements the EC Birds Directive (79/409) and which protects all wild birds, their eggs and nests. The European subspecies of the otter is listed as "globally threatened" on the IUCN/WCMC Red Data list. It is also listed on Appendix I of CITES, Appendix II of the Bern Convention, and Annexes II and IV of the Habitats Directive (92/43/EEC). Under current legislation, therefore, killing fish eating birds or otters to reduce their predation on eel numbers is not an option being considered by the Environment Agency.

\section{> FUTURE DEVELOPMENTS IN ASSESSMENT PROCEDURES}

While the RCM is the most practical model to apply in the early development of English and Welsh EMPs, its utility in the long term is limited because it is based on eel densities rather than biomass, on yellow eel rather than silver eel production, and because it generally cannot be used to simulate the effects of management measures or assess their relative contributions to population enhancement (but see stocking, above). A more complete, but also more data-intensive approach, is spatial modelling of eel life history from glass eel to silver eel stages, incorporating natural life history processes (e.g. growth, sex differentiation, migration, natural mortality, effects of density dependence) and anthropogenic inputs (e.g. stocking) and impacts (e.g. mortalities from fishing or turbines, barriers to habitats).

Several spatial, life history models are under development, and some were reviewed in the EU-SLIME project (Dekker et al., 2006). The Scenario-based Model for Eel Populations (SMEP) (Aprahamian et al., 2007) and GlobAng (Lambert and Rochard, 2007) share common approaches to modelling eel production within river basins. While there is a lot of growth data eels from UK rivers (Aprahamian, 1988, 2000; Bark et al., 2007), there is a limited understanding of other processes, or how they might be influenced by density and habitat. Furthermore, the application of spatial models such as these requires the quantification of the eel-producing habitat, and ideally an understanding of the potential production of the various habitats, including how this potential varies with distance from the sea, etc. The Environment Agency's EQR offers one approach to improving our understanding of this theme, and the influence of habitat on eel production is the subject of Government funded research in the UK.

For most Member States, it is unlikely that enough resources will be available to populate models solely on data derived from eel-specific surveys. In most cases, therefore, the models will need to rely on eel data gathered from general purpose, multi-species surveys. An example of how such data can be used to assist in management is provided by Lasne and Laffaille (2008), in their assessment of the impact of barriers on eel distribution. This approach could be further developed and incorporated into a more "global" model.

This complex, spatial modelling approach needs further development, and it has been suggested that a single European model or 'toolbox' is required to facilitate assessment and enhancement of the eel at a European stock level. In order to develop this most costeffectively, we suggest that co-ordination is needed across Europe, and that this might be best achieved through the EC Commission.

The views expressed in this paper are those of the authors and not necessarily those of the Environment Agency or Cefas. 


\section{ACKNOWLEDGEMENTS}

We are grateful to the Marine and Fisheries Agency for permission to publish extracts from their database, and to various Environment Agency staff for permission to present data from Eel Management Plans. Thanks also to Mike Pawson and Laurent Beaulaton for their constructive comments on drafts of the manuscript.

\section{REFERENCES}

Anon, 1086. The Domesday Book (English translation 1977, Morris J.), Phillimore, London.

Aprahamian M.W., 1987. Use of the burning technique for age determination in eels (Anguilla anguilla (L.)) derived from the stocking of elvers. Fish. Res., 6, 93-96.

Aprahamian M.W., 1988. Age structure of eel, Anguilla anguilla (L.), populations in the River Severn, England, and the River Dee, Wales. Aquacult. Fish. Manage., 19, 365-376.

Aprahamian M.W., 2000. The growth rate of eel in tributaries of the lower River Severn, England, and its relationship with stock size. J. Fish Biol., 56, 223-227.

Aprahamian M.W., Walker A.M., Williams B., Bark A. and Knights B., 2007. On the application of models of European eel Anguilla anguilla production and escapement to the development of Eel Management Plans: the River Severn. ICES J. Mar. Sci., 64, 1472-1482.

Bark A., Williams B. and Knights B., 2007. Current status and temporal trends in stocks of European eel in England and Wales. ICES J. Mar. Sci., 64, 1368-1378.

Dekker W., Pawson M., Walker A., Rosell R., Evans D., Briand C., Castelnaud G., Lambert P., Beaulaton L., Åström M., Wickström H., Poole R., McCarthy T.K., Blaszkowski M., De Leo G. and Bevacqua D., 2006. Report of FP6-project FP6-022488, Restoration of the European eel population; pilot studies for a scientific framework in support of sustainable management: SLIME, Sixth Framework Programme, Priority 8.1, Policy-oriented research, Scientific Support to Policies, $19 \mathrm{p}$.

Environment Agency, 2005. Screening for Intake and Outfalls: a best practice guide, Science Report SC030231, Environment Agency, Bristol, $154 \mathrm{p}$.

Foster J. and Block D., 2006. The Sussex Eel Project, Environment Agency Ecological Appraisal, Report No. F001EEL05-6, Environment Agency, Bristol, 16 p.

Hunt W., 2007. The Victorian Elver Wars, Reardon Publishing, Cheltenham, 52 p.

Ibbotson A., Smith J., Scarlett P. and Aprahamian M.W., 2002. Colonisation of freshwater habitats by the European eel Anguilla anguilla. Freshwater Biol., 47, 1696-1706.

ICES/EIFAC, 2006. Report of the 2006 session of the Joint EIFAC/ICES Working Group on Eels, Rome, 23-27 January 2006, EIFAC Occasional Paper No. 38, ICES CM 2006/ACFM: 16, Rome, FAO/Copenhagen, ICES, 2006, $352 \mathrm{p}$.

ICES/EIFAC, 2007. Report of the 2007 session of the Joint EIFAC/ICES Working Group on Eels, Bordeaux, France, 3-7 September 2007, EIFAC Occasional Paper No. 38, ICES CM 2007/ACFM: 23, Bordeaux/Copenhagen, ICES, 2007, 526 p.

Knights B., 2001. Economic Evaluation of Eel and Elver Fisheries in England and Wales (Module C), Environment Agency R\&D, Technical Report W2-039/TR/2, $50 \mathrm{p}$.

Knights B., White E. and Naismith I.A., 1996. Stock assessment of European eel, Anguilla anguilla L. In: Cowx I. (ed.), Stock Assessment in Inland Fisheries, Fishing News Books, Blackwell Science, Oxford, 431-446.

Knights B., Bark A., Ball M., Williams F., Winter E. and Dunn S., 2001. Eel and Elver Stocks in England and Wales - Status and Management Options, Environment Agency R\&D, Technical Report W248, Bristol, $294 \mathrm{p}$.

Lambert P. and Rochard E., 2007. Identification of the inland population dynamics of the European eel using pattern-oriented modelling. Ecol. Model., 206, 166-178.

Lasne E. and Laffaille P., 2008. Analysis of distribution patterns of yellow European eels in the Loire catchment using logistic models based on presence-absence of different size-classes. Ecol. Freshw. Fish, 17, 30-37.

Naismith I.A. and Knights B., 1993. The distribution, density and growth of the European eel, Anguilla anguilla, in the freshwater catchment of the River Thames. J. Fish Biol., 42, 217-226.

Watson E.P.K. and McCubbing D.J.F., 1997. The effects of environmental stimuli on the downstream migration of the common eel (Anguilla anguilla) on the River Leven in Cumbria, Internal Environment Agency Report. 